\title{
Effects of organic residue management and legume cover on growth of pine seedlings, nutrient leaching and soil properties
}

\author{
María X. GóMEZ-ReY*, Manuel MADEIRA, Ernesto VASCONCELos \\ Departamento de Ciências do Ambiente, Instituto Superior de Agronomia, Tapada de Ajuda, 1349-017 Lisboa, Portugal
}

(Received 4 December 2007; accepted 4 August 2008)

\author{
Keywords: \\ Pinus pinaster / \\ harvest residues / \\ forest floor litter / \\ Nitrogen / \\ legume cover cropping
}

\begin{abstract}
- The short-term effect of organic residue management on the growth and nutrition of Pinus pinaster Ait. seedlings, and on nutrient leaching and chemical properties of an acid soil was assessed through a lysimeter experiment. Treatments included absence, placement on the soil surface, and incorporation into the soil (with and without legume cover cropping) of organic residues (forest floor litter or forest floor litter plus harvest residues).

- Residues placed on the soil surface enhanced seedling growth. Organic residues reduced nutrient losses $\left(\mathrm{NO}_{3}^{-}, \mathrm{Ca}\right.$ and $\left.\mathrm{Mg}\right)$ and resulted in nutrient accumulation in the soil. Harvest residues positively affected $\mathrm{K}$ seedling nutrition status and enhanced $\mathrm{K}$ soil accumulation.

- Legume cover cropping reduced soil nutrient losses ( $\mathrm{N}, \mathrm{Ca}, \mathrm{Mg}$ and $\mathrm{K}$ ) during the early stage of seedling growth; it also improved seedling nutrition status ( $\mathrm{N}$ and $\mathrm{P}$ ), but without any effect on growth.

- Harvest residues plus forest floor litter placed on the soil surface was the most appropriate management to both reduce nutrient losses through leaching and increase height of seedlings at the end of the experimental period (two years).
\end{abstract}

Mots-clés :

Pinus pinaster /

résidus de récolte /

litière forestière /

azote /

couverture de légumineuse
Résumé - Effets de la gestion de résidus organiques et d'un couvert de légumineuses sur la croissance de semis de pin, le lessivage des nutriments et les propriétés du sol.

- L'effet à court terme de gestion des résidus organiques sur la croissance et la nutrition de semis de Pinus pinaster Ait. et sur le lessivage des nutriments et sur les propriétés chimiques d'un sol acide a été évalué par une expérimentation en lysimétre. Les traitements ont inclus l'absence, le placement à la surface du sol et l'incorporation dans le sol (avec et sans couverture de légumineuse) de résidus organiques (litière forestière ou litière forestière plus résidus de récolte).

- Les résidus placés à la surface de sol ont augmenté la croissance des jeunes plants. Les résidus organiques ont réduit les pertes en nutriments $\left(\mathrm{NO}_{3}^{-}, \mathrm{Ca}, \mathrm{Mg}\right)$ et ont abouti à l'accumulation de nutriments dans le sol. Les résidus de récolte ont positivement affecté le statut nutritionnel en $\mathrm{K}$ des jeunes plants et ont augmenté l'accumulation de K dans le sol.

- Une couverture de légumineuse réduit les pertes de substances nutritives du sol ( $\mathrm{N}, \mathrm{Ca}, \mathrm{Mg}$ et $\mathrm{K}$ ) pendant la première période de croissance du jeune plant; elle améliore aussi le statut nutritionnel du jeune plant $(\mathrm{N}$ et $\mathrm{P})$, mais sans aucun effet sur la croissance.

- Les résidus de récolte plus la litière forestière placés à la surface de sol ont constitués la gestion la plus appropriée pour à la fois réduire les pertes en nutriments par lessivage et accroître la hauteur des jeunes plants à la fin de la période d'expérimentation (deux ans).

\section{INTRODUCTION}

Plantations of Pinus pinaster represent the largest forest area in Portugal and currently reach $7.1 \times 10^{5}$ ha (IFN, 2006). These plantations are mainly located in the northern and central regions of the country, where they mostly occupy soils

*Corresponding author: mxgomez@ isa.utl.pt with low nutrient status (Podzols, dystric Cambisols and dystric Regosols), which are highly sensitive to management operations resulting in major losses of nutrients. At the end of the rotation (70-80 years) of pine plantations growing in sandy soils, harvest residues can contain a substantial amount of nutrients (425 and $673 \mathrm{~kg} \mathrm{ha}^{-1}$ of $\mathrm{N}$ and $\mathrm{Ca}$, respectively); the amounts of both nutrients in the forest floor litter layer can reach about $300 \mathrm{~kg} \mathrm{ha}^{-1}$ (PRAXIS, 2001). Therefore, practices 
of site preparation that include removal of harvest residues and the forest floor layer may considerably reduce soil fertility and can lead to negative nutrient budgets, such as observed in pine plantations in Northern Spain (Dambrine et al., 2000; Merino et al., 1998). In this context, management of organic residues during the inter-rotation period is a crucial factor for maintaining fertility and sustained productivity in those plantations. In fact, the removal of harvest residues to minimize fire risks and to supply future power stations has been encouraged (DGRF, 2006), although little attention has been given to the effects of such practices on the nutrient status of forest soils and on long-term site productivity.

Organic residue management practices could affect environmental soil conditions and alter decomposition rates of organic residues and the subsequent mineralization and availability of nutrients (Smethurst and Nambiar, 1990). Retention of harvest residues at the site, especially branches with high $\mathrm{C} / \mathrm{N}$ ratios, have a potential capacity for $\mathrm{N}$ immobilization during their decomposition. This effect reduces losses of $\mathrm{N}$ by leaching in the first years after harvesting (Smethurst and Nambiar, 1995) when mineral $\mathrm{N}$ in the soil may be in excess for young tree requirements. Those residues release immobilized $\mathrm{N}$ at a later stage of decomposition, offering a greater synchrony between supply and demand by growing trees (Johnson, 1995). Furthermore, management options that increase the degree contact between organic residues and soil can enhance favorable conditions for microbial activity and, thus, accelerate the decomposition process (Carlyle et al., 1998; Pérez-Batallón et al., 2001).

The use of $\mathrm{N}$-fixing leguminous plants may also contribute to improving soil fertility, since they incorporate organic matter and $\mathrm{N}$ in the soil (Corbeels et al., 2003) and reduce nutrient losses through leaching during the early stage of plantation development (Aggangan et al., 1999). This may also promote tree growth in forest plantations (Nambiar and Nethercott, 1987) and decrease competition from weeds (Alley et al.,1999; Smethurst and Nambiar, 1990). However, leguminous plants may compete for site resources, and pine growth suppression has also been reported (Alley et al., 1999; Gakis et al., 2004).

In this context, a lysimeter experiment was carried out under controlled conditions, over 24 months, to evaluate the short-term effects of removal, maintenance on the soil surface and incorporation into the soil (with or without legume cover cropping) of organic residues (forest floor litter alone or combined with harvest residues) on the growth and nutrition status of Pinus pinaster seedlings, nutrient leaching, and soil chemical properties.

\section{MATERIALS AND METHODS}

\subsection{Lysimeter station}

The study was carried out in a lysimeter station located at the Instituto Superior de Agronomia, Lisboa. The area has a Mediterranean climate, tempered by an oceanic influence. The 30-year mean (1971-2000) rainfall monitored in the adjacent meteorological station of Lisboa/Ajuda was $675 \mathrm{~mm}$ and the mean annual temperature was $16.4{ }^{\circ} \mathrm{C}$, ranging from a monthly mean of $11.8{ }^{\circ} \mathrm{C}$ in January to $21.0^{\circ} \mathrm{C}$ in August (INMG, 2007). During the experimental period (January 1998-February 2000) rainfall was 459, 750 and $44 \mathrm{~mm}$, respectively, in 1998, 1999 and 2000 (January and February).

The lysimeter station consisted of 28 lysimeters constructed in PVC, with a surface area of $0.28 \mathrm{~m}^{2}$, an inner diameter of $0.6 \mathrm{~m}$ and a depth of $1 \mathrm{~m}$. Each lysimeter had, at its bottom, a drainage system $10 \mathrm{~cm}$ thick constituting, from the bottom to the top, a double plastic mesh (2 mm), a gravel layer washed with deionized water, a double layer of filtering material (Terram) and a washed sand layer, which was directly in contact with the experimental soil substrate. In the lysimeter base, a hole was connected, through a plastic tube, to a sampling bottle $(5 \mathrm{~L})$, where leachates were continuously collected. Lysimeters were exposed to weather conditions in an open fenced area, to avoid animal access, and adjacent to the aforementioned meteorological station. They were placed $1 \mathrm{~m}$ apart on a concrete base with openings for the drainage tubes, the surrounding space between them having been filled with sand material covered by pine bark. The lysimeters' top edges were $15 \mathrm{~cm}$ above the covering bark surface.

\subsection{Materials}

The mineral soil and the organic residues used in the experiment were collected from an 80-year-old maritime pine plantation (Pinus pinaster) in the Leiria National Forest (lat. $39^{\circ} 42^{\prime} \mathrm{N}$; long. $8^{\circ} 03^{\prime} \mathrm{W}$; $40 \mathrm{~m}$ a.s.1.), located in central coastal Portugal. The plantation density was about 200 tree ha $^{-1}$ and its productivity (commercial timber with bark) was $6 \mathrm{~m}^{3}$ ha $^{-1} \mathrm{y}^{-1}$ (PRAXIS, 2001).

Soils are mostly Haplic Arenosols (WRN, 2006) developed on coastal sand dunes. Soil substrates were collected from an Ah horizon and a $\mathrm{C}$ horizon. Each soil substrate was sieved $(<2 \mathrm{~mm})$ and six subsamples were taken for analysis. Both horizons were sandy and their characteristics are shown in Tab. I. The Ah horizon had lower $\mathrm{pH}$ (4.8), and a greater organic $\mathrm{C}$ content $\left(22.2 \mathrm{~g} \mathrm{~kg}^{-1}\right)$ and $\mathrm{C} / \mathrm{N}$ ratio (35.8) than the $\mathrm{C}$ horizon.

The forest floor litter layer ( $\mathrm{L}$ and $\mathrm{F}$ layers) and harvest residues (green needles, 0.5-5.0 cm diameter branches and cones) were collected at harvesting time (November, 1997), by randomized sampling of $1 \mathrm{~m}^{2}$ areas for a total of five samples for each material. Samples were dried $\left(80^{\circ} \mathrm{C}\right)$, and subsamples were taken for chemical analysis.

\subsection{Treatments}

Effects of organic residue management were assessed through three main options: absence of organic residues, presence of forest floor and presence of forest floor plus harvest residues. Options related to residue placement (on the surface or incorporated into the soil) and legume cover cropping were also considered. Specifically, seven treatments were installed as described in Tab. II. Treatments were replicated four times and were established at random.

In each lysimeter, over the respective drainage system, were placed $180 \mathrm{~kg}\left(105^{\circ} \mathrm{C}\right.$ dry weight $)$ of sieved homogenized mineral soil of the $\mathrm{C}$ horizon (about $0.45 \mathrm{~m}$ depth), packed at a bulk density of about $1.4 \mathrm{~g} \mathrm{~cm}^{-3}$; over this material were placed $130 \mathrm{~kg}$ of the A horizon (about $0.35 \mathrm{~m}$ depth, bulk density of about $1.3 \mathrm{~g} \mathrm{~cm}^{-3}$ ). Except in the treatment NR, $2.5 \mathrm{~kg}$ (dry weight) of forest floor litter were applied in each lysimeter. In the treatments LHS, LHI and LHL, $0.5 \mathrm{~kg}$ of needles, $2.4 \mathrm{~kg}$ of branches (cut into 20 -cm long pieces) and 
Table I. Particle size, $\mathrm{pH}$ values and contents of organic $\mathrm{C}$, total N, extractable bases, $\mathrm{Al}$ and $\mathrm{P}$ of soil mineral substrates $\left(<2 \mathrm{~mm}, 105{ }^{\circ} \mathrm{C}\right.$ dry weight) used in the lysimeters.

\begin{tabular}{|c|c|c|c|c|c|c|c|c|c|c|c|c|}
\hline \multirow[t]{3}{*}{ Horizon } & \multicolumn{3}{|c|}{ Particle size } & \multirow[t]{2}{*}{$\mathrm{C}$} & \multirow[t]{2}{*}{$\mathrm{N}$} & \multirow{3}{*}{$\begin{array}{c}\mathrm{pH} \\
\mathrm{H}_{2} \mathrm{O}\end{array}$} & \multicolumn{4}{|c|}{ Extractable bases } & \multirow[t]{2}{*}{$\mathrm{Al}^{+3}$} & \multirow[t]{2}{*}{$\mathrm{P}$} \\
\hline & Sand & Silt & Clay & & & & $\mathrm{Ca}^{2+}$ & $\mathrm{Mg}^{2+}$ & $\mathrm{Na}^{+}$ & $\mathrm{K}^{+}$ & & \\
\hline & \multicolumn{5}{|c|}{$\mathrm{g} \mathrm{kg}^{-1}$} & & \multicolumn{5}{|c|}{$\mathrm{cmol}_{c} \mathrm{~kg}^{-1}$} & $\overline{\mathrm{mg} \mathrm{kg}^{-1}}$ \\
\hline \multirow[t]{2}{*}{$\mathrm{Ah}$} & 974 & 20 & 6 & 22.2 & 0.62 & 4.83 & 2.51 & 0.56 & 0.15 & 0.09 & 0.15 & 5.6 \\
\hline & \pm 9 & \pm 3 & \pm 6 & \pm 9.3 & \pm 0.27 & \pm 0.43 & \pm 1.12 & \pm 0.28 & \pm 0.04 & \pm 0.04 & \pm 0.10 & \pm 1.9 \\
\hline \multirow[t]{2}{*}{$\mathrm{C}$} & 983 & 10 & 7 & 0.2 & 0.02 & 5.84 & 0.06 & 0.01 & 0.12 & 0.01 & 0.03 & 3.0 \\
\hline & \pm 9 & \pm 11 & \pm 7 & \pm 0.1 & \pm 0.01 & \pm 0.14 & \pm 0.03 & \pm 0.00 & \pm 0.05 & \pm 0.00 & \pm 0.01 & \pm 1.0 \\
\hline
\end{tabular}

Values are means $(n=6) \pm$ standard deviation (S.D.).

Table II. Description of treatments.

\begin{tabular}{lccc}
\hline Treatment & Forest litter & Harvest residue & Legume \\
\hline NR & - & - & - \\
LS & Surface & - & - \\
LI & Incorporated & - & - \\
LL & Incorporated & - & Yes \\
LHS & Surface & Surface & - \\
LHI & Incorporated & Incorporated & - \\
LHL & Incorporated & Incorporated & Yes \\
\hline
\end{tabular}

$0.5 \mathrm{~kg}$ of cones were also applied in each lysimeter. The amounts of harvest residues were about two times greater than those measured in an 80-year-old pine plantation (PRAXIS, 2001).

In the LI, LL, LHI and LHL treatments, residues were mixed with the Ah horizon and introduced into the top 30-35 cm depth of lysimeters. One seedling of $P$. pinaster was planted on 27 January 1998 in each lysimeter. A uniform set of seedling plants was used with similar vigor and growth $(15.9 \mathrm{~cm}$ height). Each seedling received $10 \mathrm{~g}$ of NP fertilizer (18:21). In the treatments LL and LHL, a legume (Lupinus luteus) was seeded twice (January, 1998 and 1999) at a rate of $107 \mathrm{~kg} \mathrm{ha}^{-1}$. Treatment installation was concluded in 29 January 1998. Herbaceous plants other than L. luteus in lysimeters were controlled by hand.

Irrigation water was applied in lysimeters (depending on the frequency of rainwater) to maintain soil moisture above $60 \%$ of available water capacity (difference between water content at 6.2 and $1500 \mathrm{kPa}$ ), moisture being measured by Time Domain Reflectometry (6050X1 Trase System, Soil Moisture Equipment Corp., CA, USA). In the NR treatment, a pair of stainless steel wave guides $60 \mathrm{~cm}$ long was permanently inserted into the soil of each lysimeter and measurements were carried out daily. On 9 and 16 March 1998, $\left(\mathrm{NH}_{4}\right)_{6} \mathrm{Mo}_{7} \mathrm{O}_{24}$ was added in treatments LL and LHL through irrigation water to promote $L$. luteus development. Over the experimental period, the total amount of water applied was $414 \mathrm{~mm}$ in all treatments. Amounts of nutrients supplied in the lysimeters of each treatment are shown in Table III.

\subsection{Measurements and sampling}

The height of seedlings was measured monthly for 24 months. From 27 September 1998, basal stem diameter at $5 \mathrm{~cm}$ above ground level was measured using a digital caliper. To assess seedling nutrition status, eight pairs of needles were sampled from the upper
Table III. Amounts of nutrients (g) supplied per lysimeter as fertilizer, irrigation, rainfall, forest floor litter and harvest residues.

\begin{tabular}{lccccc}
\hline & $\mathrm{N}$ & $\mathrm{Ca}$ & $\mathrm{Mg}$ & $\mathrm{K}$ & $\mathrm{P}$ \\
\hline Fertilizer & 1.800 & 0.000 & 0.000 & 0.000 & 0.916 \\
Irrigation & 0.060 & 1.250 & 0.217 & 0.068 & $<0.001$ \\
Rainfall & 0.194 & 0.916 & 0.098 & 0.087 & $<0.001$ \\
Forest floor litter & 8.075 & 10.600 & 1.500 & 2.325 & 0.375 \\
Harvest residues & 13.282 & 19.358 & 2.914 & 4.642 & 0.719 \\
\hline
\end{tabular}

half of the canopy of each seedling on two occasions (November 1998 and 1999).

Tree seedling sampling to determine biomass and respective nutrient contents was performed in March 2000. All seedlings were cut at the base and root systems were pulled out from the soil. Dry weight of each component was calculated from total fresh weight and moisture content, and a subsample was taken for subsequent chemical analysis.

Samplings to assess legume biomass and nutrient content took place in May 1998 and 1999, when plants reached the flowering stage. Legume plants were pulled out from the soil, and above- and belowground components were separated, weighed and dried. A subsample was used for chemical analysis. Later, plant components were spread over the soil surface in the LL and LHL treatments.

Samples of rainwater, according to rainfall events, were collected for analysis using an open collector placed in the adjacent meteorological station. The volume of lysimeter leachates was recorded and subsamples were collected for analysis according to rainfall events. Both rainwater and leachate subsamples were stored at $-15^{\circ} \mathrm{C}$ immediately after collection.

Soil was sampled at the end of the experiment (March 2000), before destructive tree sampling. In each lysimeter, after removal of organic residues remaining on the soil surface, four soil cores $(65 \mathrm{~mm}$ diameter) were collected from three depths (0-10, 10-20 and 20$30 \mathrm{~cm}$ ), and combined in a composite sample for each lysimeter, which was dried $\left(45^{\circ} \mathrm{C}\right)$ and sieved $(<2 \mathrm{~mm})$.

\subsection{Laboratory procedures}

Organic residues were dried at $45{ }^{\circ} \mathrm{C}$ and ground in a laboratory mill to a particle size of $0.5 \mathrm{~mm}$. The mineral elements $(\mathrm{Ca}, \mathrm{Mg}, \mathrm{K}$ and $\mathrm{P})$ were determined after ashing $\left(6 \mathrm{~h}\right.$ at $\left.450{ }^{\circ} \mathrm{C}\right)$ which was taken up in $\mathrm{HCl}$. Total $\mathrm{N}$ was determined using Kjeldhal digestion. The carbon content was measured by wet oxidation. The $\mathrm{Ca}, \mathrm{Mg}$ and $\mathrm{K}$ 
Table IV. Height $(\mathrm{cm})$ and diameter $(\mathrm{mm})$ of seedlings after 12 and 24 months of study (February 1999 and 2000), and total biomass (g/lysimeter, dry weight) at the end of the experiment (March 2000). Values are means $(n=4) \pm$ S.D.

\begin{tabular}{|c|c|c|c|c|c|}
\hline \multirow[t]{2}{*}{ Treatment } & \multicolumn{2}{|c|}{ Height } & \multicolumn{2}{|c|}{ Diameter } & \multirow{2}{*}{$\begin{array}{c}\text { Biomass } \\
\text { March } 2000\end{array}$} \\
\hline & Feb 1999 & Feb 2000 & Feb 1999 & Feb 2000 & \\
\hline NR & $5.3 \pm 10.1$ & $8.3 \pm 8.3 b$ & $0.0 \pm 0.8 \mathrm{ac}$ & $7.8 \pm 0.7 \mathrm{ab}$ & $805.6 \pm 100.7 \mathrm{ab}$ \\
\hline LI & $70.3 \pm 4.2$ & $94.7 \pm 4.6 \mathrm{~b}$ & $17.7 \pm 0.5 \mathrm{~b}$ & $26.6 \pm 2.3 \mathrm{ab}$ & $738.6 \pm 59.8 \mathrm{ab}$ \\
\hline LL & $65.3 \pm 4.1$ & $96.0 \pm 2.9 \mathrm{~b}$ & $20.2 \pm 0.8 \mathrm{c}$ & $26.0 \pm 3.2 \mathrm{ab}$ & $674.0 \pm 161.2 b$ \\
\hline LHS & $85.3 \pm 15.9$ & $116.0 \pm 9.6 \mathrm{a}$ & $18.5 \pm 0.2 \mathrm{abc}$ & $30.2 \pm 1.3 \mathrm{a}$ & $960.5 \pm 135.7 \mathrm{a}$ \\
\hline LHL & $67.3 \pm 4.5$ & $94.3 \pm 2.5 b$ & $19.3 \pm 0.8 \mathrm{abc}$ & $26.2 \pm 0.7 \mathrm{ab}$ & $851.6 \pm 91.8 \mathrm{ab}$ \\
\hline
\end{tabular}

Different letters in the same column denote significant differences $(p<0.05)$ among treatments by the Tukey multiple range test.

Table V. Results of Multifactor ANOVAs showing the effects of residue type (forest floor litter or harvest residues), residue placement (soil surface or incorporation into the soil) and legumes (presence or absence) on height $(\mathrm{cm})$ and diameter (mm) (February 2000) and total biomass (g/lysimeter) of tree seedlings (March 2000), and on nutrient content in green needles ( $\mathrm{mg} \mathrm{g}^{-1}$, November 1998 and 1999) and nutrient content in tree seedling biomass (g/lysimeter) (March 2000). Levels of significance: ${ }^{* * *} p<0.001,{ }^{* *} p<0.01,{ }^{*} p<0.05$ and n.s. not significant.

\begin{tabular}{|c|c|c|c|c|c|c|c|c|c|c|c|c|c|c|}
\hline \multirow{3}{*}{ Factors } & \multicolumn{3}{|c|}{ Seedlings } & \multicolumn{6}{|c|}{ Green needles } & \multicolumn{5}{|c|}{ Seedling biomass } \\
\hline & & & & $\mathrm{N}$ & $\mathrm{N}$ & $\mathrm{K}$ & $\mathrm{K}$ & $\mathrm{P}$ & $\mathrm{P}$ & $\mathrm{N}$ & $\mathrm{Ca}$ & $\mathrm{Mg}$ & $\mathrm{K}$ & $\mathrm{P}$ \\
\hline & Height & Diameter & Biomass & 1998 & 1999 & 1998 & 1999 & 1998 & 1999 & & & & & \\
\hline Residue & n.s. & n.s. & $*$ & n.s. & n.s. & n.s. & $* *$ & n.s. & n.s. & $* *$ & n.s. & n.s. & $* * *$ & $* * *$ \\
\hline Placement & $* * *$ & $* *$ & $*$ & n.s. & n.s. & n.s. & n.s. & n.s. & n.s. & $*$ & $* *$ & $* *$ & n.s. & $*$ \\
\hline Legume & n.s. & n.s. & n.s. & $* * *$ & $* *$ & n.s. & $*$ & $* *$ & $* *$ & $*$ & n.s. & n.s. & n.s. & n.s. \\
\hline Residue $\times$ Placement & n.s. & n.s. & n.s. & n.s. & n.s. & $* *$ & n.s. & n.s. & n.s. & n.s. & $*$ & n.s. & $*$ & n.s. \\
\hline Residue $\times$ Legume & n.s. & n.s. & n.s. & n.s. & n.s. & $*$ & n.s. & n.s. & n.s. & n.s. & $* *$ & n.s. & n.s. & n.s. \\
\hline
\end{tabular}

were measured by atomic absorption spectrometry (AAS) and P by colorimetry.

Samples of rainwater and leachates were centrifuged and filtered through a $0.45-\mu \mathrm{m}$ membrane and $\mathrm{pH}$ was measured. Concentrations of $\mathrm{NO}_{3}^{-}-\mathrm{N}$ and $\mathrm{NH}_{4}^{+}-\mathrm{N}$ (limit of detection $0.01 \mathrm{mg} \mathrm{L}^{-1}$ ) were determined with a segmented flow autoanalyzer, using the hydrazinium reduction and the modified Berthelot method, respectively (Houba et al., 1994). The $\mathrm{Ca}, \mathrm{Mg}$ and $\mathrm{K}$ were measured by AAS, the limit of detection being $0.001 \mathrm{mg} \mathrm{L}^{-1}$. The accuracy of determinations was checked by using certified reference samples.

Soil properties were determined on the fine fraction $(<2 \mathrm{~mm})$, following the methodology described by Póvoas and Barral (1992). Soil $\mathrm{pH}$ was determined potentiometrically in water (soil:solution ratio $1: 2.5$ ). Organic $\mathrm{C}$ was determined by wet oxidation following the method described by De Leenheer and Van Hove (1958). Total N was determined using Kjeldhal digestion. Extractable P was determined using the Egnér-Riehm method (Egnér et al., 960). The extractable base cations were assessed by $1 \mathrm{M} \mathrm{NH}_{4} \mathrm{OAc}$, adjusted at $\mathrm{pH} 7.0$, and the extractable $\mathrm{Al}$ was determined after extraction with $1 \mathrm{M} \mathrm{KCl}$. The $\mathrm{Ca}, \mathrm{Mg}, \mathrm{Na}, \mathrm{K}$ and $\mathrm{Al}$ were measured by AAS and $\mathrm{P}$ by colorimetry.

\subsection{Statistical analysis}

Treatment effects on growth and nutrition status of seedlings, nutrient leaching, and soil chemical properties were tested by analysis of variance (ANOVA) and comparison among treatment means using the Tukey multiple range test. In order to discriminate the rela- tive importance of the key factors that were established (residue type, residue placement and legumes), a 3-factor analysis of variance was carried out. Statistical procedures were performed using Statgraphics plus 5.1 (Manugistics Inc.).

\section{RESULTS}

\subsection{Seedling growth and biomass}

Over the experimental period, seedling growth parameters (height, diameter and total biomass) of the treatment without organic residues (control) were mostly of the same magnitude as those observed in the other treatments (Tab. IV). However, at the end of the study, the seedling height in the treatments with organic residues placed on the soil surface (LS and LHS) was significantly greater than in control. Residues placed on the soil surface significantly increased seedling height $(p<$ $0.001)$ and diameter $(p<0.01)$ by 23 and $19 \%$, respectively, in comparison with their incorporation (Tab. V). The growth increase was irrespective of the residue type (no significant residue $\times$ placement interaction). Tree seedling total biomass was significantly affected $(p<0.05)$ by both residue type and placement. Legume cover cropping did not lead to significant differences in height, diameter or seedling biomass. 
Table VI. Aboveground and belowground biomass (g/lysimeter, dry weight) and contents of nutrients (g/lysimeter) in legumes, in the LL and LHL treatments. Values are means $\pm \mathrm{SD}(n=4)$. Differences between treatments were not statistically significant $(p>0.05$, ANOVA procedure).

\begin{tabular}{lccccccc}
\hline Treat & Above-ground & Below-ground & $\mathrm{N}$ & $\mathrm{Ca}$ & $\mathrm{Mg}$ & $\mathrm{K}$ \\
\hline LL & $74.6 \pm 34.4$ & $19.4 \pm 3.8$ & $1.88 \pm 0.40$ & $0.57 \pm 0.10$ & $0.26 \pm 0.05$ & $1.26 \pm 0.42$ & $0.16 \pm 0.02$ \\
LHL & $74.4 \pm 43.1$ & $20.1 \pm 4.1$ & $2.30 \pm 0.48$ & $0.58 \pm 0.12$ & $0.31 \pm 0.08$ & $1.34 \pm 0.65$ & $0.19 \pm 0.05$ \\
\multicolumn{7}{c}{ May 1999} & \multicolumn{2}{c}{ May 1998 } \\
LL & $31.0 \pm 10.2$ & $7.9 \pm 2.6$ & $0.79 \pm 0.24$ & $0.21 \pm 0.06$ & $0.08 \pm 0.02$ & $0.38 \pm 0.10$ & $0.06 \pm 0.01$ \\
LHL & $17.1 \pm 6.0$ & $4.4 \pm 1.5$ & $0.43 \pm 0.09$ & $0.12 \pm 0.04$ & $0.05 \pm 0.01$ & $0.29 \pm 0.09$ & $0.02 \pm 0.01$ \\
\hline
\end{tabular}

Table VII. Contents $\left(\mathrm{mg} \mathrm{g}^{-1}\right)$ of N, K and P in green needles over the experiment period (November 1998 and 1999), and in tree seedling biomass (g/lysimeter) at the end of the experiment (March 2000).

\begin{tabular}{|c|c|c|c|c|c|c|c|c|c|c|c|}
\hline \multirow[t]{3}{*}{ Treatements } & \multicolumn{6}{|c|}{ Green needles } & \multicolumn{5}{|c|}{ Seedling biomass } \\
\hline & \multicolumn{2}{|c|}{$\mathrm{N}$} & \multicolumn{2}{|c|}{$\mathrm{K}$} & \multicolumn{2}{|c|}{$\mathrm{P}$} & \multirow[t]{2}{*}{$\mathrm{N}$} & \multirow[t]{2}{*}{$\mathrm{Ca}$} & \multirow[t]{2}{*}{$\mathrm{Mg}$} & \multirow[t]{2}{*}{ K } & \multirow[t]{2}{*}{$\mathrm{P}$} \\
\hline & 1998 & 1999 & 1998 & 1999 & 1998 & 1999 & & & & & \\
\hline \multirow[t]{2}{*}{ NR } & 14.2 & 5.9 & 8.2 & 3.4 & 1.1 & 0.5 & 3.37 & 2.49 & 0.66 & 1.27 & 0.33 \\
\hline & $\pm 1.3 \mathrm{a}$ & $\pm 0.4 \mathrm{a}$ & $\pm 0.4 \mathrm{ab}$ & $\pm 0.5 \mathrm{a}$ & \pm 0.1 & $\pm 0.0 \mathrm{a}$ & $\pm 0.51 \mathrm{ab}$ & $\pm 0.22 \mathrm{ab}$ & $\pm 0.10 \mathrm{ab}$ & $\pm 0.24 \mathrm{a}$ & $\pm 0.05 \mathrm{ab}$ \\
\hline \multirow[t]{2}{*}{ LS } & 11.0 & 5.3 & 8.6 & 3.2 & 1.0 & 0.5 & 3.72 & 3.20 & 0.81 & 1.36 & 0.37 \\
\hline & $\pm 0.7 \mathrm{~b}$ & $\pm 0.2 \mathrm{a}$ & $\pm 0.8 \mathrm{ab}$ & $\pm 0.4 \mathrm{a}$ & \pm 0.0 & $\pm 0.0 \mathrm{a}$ & $\pm 0.23 \mathrm{ab}$ & $\pm 0.21 \mathrm{a}$ & $\pm 0.01 \mathrm{a}$ & $\pm 0.21 \mathrm{a}$ & $\pm 0.03 \mathrm{ab}$ \\
\hline \multirow[t]{2}{*}{ LI } & 12.0 & 5.9 & 8.4 & 4.1 & 1.0 & 0.6 & 3.17 & 2.32 & 0.68 & 1.43 & 0.29 \\
\hline & $\pm 1.0 \mathrm{ab}$ & $\pm 0.6 \mathrm{a}$ & $\pm 1.3 \mathrm{ab}$ & $\pm 0.4 \mathrm{a}$ & \pm 0.0 & $\pm 0.1 \mathrm{a}$ & $\pm 0.29 \mathrm{a}$ & $\pm 0.38 \mathrm{~b}$ & $\pm 0.05 \mathrm{ab}$ & $\pm 0.11 \mathrm{a}$ & $\pm 0.04 \mathrm{a}$ \\
\hline \multirow[t]{2}{*}{ LL } & 14.8 & 9.5 & 7.9 & 4.7 & 1.2 & 0.8 & 3.45 & 1.52 & 0.51 & 1.32 & 0.32 \\
\hline & $\pm 2.2 \mathrm{a}$ & $\pm 3.3 \mathrm{~b}$ & $\pm 0.6 \mathrm{ab}$ & $\pm 1.1 \mathrm{ab}$ & \pm 0.1 & $\pm 0.2 \mathrm{~b}$ & $\pm 0.39 \mathrm{ab}$ & $\pm 0.43 \mathrm{c}$ & $\pm 0.15 \mathrm{~b}$ & $\pm 0.36 \mathrm{a}$ & $\pm 0.07 \mathrm{a}$ \\
\hline \multirow[t]{2}{*}{ LHS } & 12.0 & 5.6 & 7.1 & 4.9 & 1.0 & 0.6 & 4.03 & 2.72 & 0.84 & 2.79 & 0.44 \\
\hline & $\pm 1.9 \mathrm{ab}$ & $\pm 0.1 \mathrm{a}$ & $\pm 0.9 \mathrm{a}$ & $\pm 0.1 \mathrm{ab}$ & \pm 0.1 & $\pm 0.0 \mathrm{a}$ & $\pm 0.51 \mathrm{ab}$ & $\pm 0.30 \mathrm{ab}$ & $\pm 0.12 \mathrm{a}$ & $\pm 0.39 \mathrm{~b}$ & $\pm 0.08 \mathrm{~b}$ \\
\hline \multirow[t]{2}{*}{ LHI } & 10.5 & 6.1 & 8.8 & 4.3 & 1.0 & 0.6 & 3.63 & 2.29 & 0.64 & 2.36 & 0.38 \\
\hline & $\pm 0.4 \mathrm{~b}$ & $\pm 0.2 \mathrm{a}$ & $\pm 0.4 \mathrm{ab}$ & $\pm 1.3 \mathrm{ab}$ & \pm 0.2 & $\pm 0.2 \mathrm{a}$ & $\pm 0.37 \mathrm{ab}$ & $\pm 0.31 \mathrm{~b}$ & $\pm 0.11 \mathrm{ab}$ & $\pm 0.20 \mathrm{bc}$ & $\pm 0.04 \mathrm{ab}$ \\
\hline \multirow[t]{2}{*}{ LHL } & 14.1 & 7.7 & 9.3 & 6.0 & 1.2 & 0.7 & 4.26 & 2.34 & 0.68 & 2.06 & 0.39 \\
\hline & $\pm 0.8 \mathrm{a}$ & $\pm 0.9 \mathrm{ab}$ & $\pm 0.5 \mathrm{~b}$ & $\pm 1.1 \mathrm{~b}$ & \pm 0.1 & $\pm 0.1 \mathrm{ab}$ & $\pm 0.72 \mathrm{~b}$ & $\pm 0.27 \mathrm{~b}$ & $\pm 0.09 \mathrm{ab}$ & $\pm 0.26 \mathrm{c}$ & $\pm 0.02 \mathrm{ab}$ \\
\hline
\end{tabular}

Values are means $(n=4) \pm$ S.D. Different letters in the same column denote significant differences $(p<0.05)$ among treatments by the Tukey multiple range test.

\subsection{Biomass and nutrient content in legumes}

Aboveground biomass was much greater in 1998 (about $74 \mathrm{~g}$ ) than in 1999 (31.0 and $17.1 \mathrm{~g}$ in the $\mathrm{D}$ and $\mathrm{G}$ treatments, respectively, Tab. VI). Belowground biomass ranged from $4.4 \mathrm{~g}$ in 1999 to $20.1 \mathrm{~g}$ in 1998 , being about $25 \%$ of the total biomass. Differences among treatments were not statistically significant. Nutrient contents were also greater in the first year of the study. The content of $\mathrm{N}(1.88-2.30 \mathrm{~g})$ in legumes, in 1998, was close to that applied as fertilizer, but much smaller than that applied as residues (Tab. III).

\subsection{Nutrient content in seedling needles}

In the first year of the experiment, contents of $\mathrm{N}$ in seedling needles (Tab. VII) of treatments with organic residues $\left(10.5-12.0 \mathrm{mg} \mathrm{g}^{-1}\right)$ were lower than in their absence
(14.2 $\left.\mathrm{mg} \mathrm{g}^{-1}\right)$, but similar contents were observed in the second year (5.3-6.1 and $5.9 \mathrm{mg} \mathrm{g}^{-1}$, respectively).

The effect of residue type on nutrient contents of seedling needles was only detected for $\mathrm{K}(p<0.01)$ at the end of the study period (Tab. V), the values being greater in the treatments including forest floor litter plus harvest residues than in those with forest floor litter only (5.21 and $4.13 \mathrm{mg} \mathrm{g}^{-1}$, respectively). In the first year, harvest residues increased $\mathrm{K}$ needle content when applied on the soil surface (interaction residue $\times$ placement, $p<0.01$ ), and when combined with legume cover cropping (interaction residue $\times$ legume, $p<0.05$ ). Residue placement options did not show significant differences in any of the nutrients analyzed in green needles. Legume cover cropping led to significantly greater $\mathrm{N}$ $(p<0.001$ and $p<0.01$, respectively, in 1998 and 1999) and $\mathrm{P}(p<0.01)$ needle contents in both years (Tab. V), and $\mathrm{K}(p<0.05)$ contents in November 1999. No significant differences for $\mathrm{Ca}$ and $\mathrm{Mg}$ contents were detected among treatments. 


\subsection{Nutrient content in tree seedling biomass}

Similar N seedling contents were observed in the treatments with organic residues (3.17-3.46 g) and in the control (3.37 g) (Tab. VII). Contents of $\mathrm{N}, \mathrm{K}$ and $\mathrm{P}$ were significantly greater in the treatments with forest floor litter plus harvest residues (4.13, 2.40 and $0.42 \mathrm{~g}$, respectively) than in those with forest floor litter only (3.60, 1.36 and $0.34 \mathrm{~g}$, respectively, Tab. V). The interaction residue $\times$ placement showed that differences in $\mathrm{K}$ contents were greater in the soil surface placement.

Residues placed on the soil surface showed higher biomass $\mathrm{N}(3.87 \mathrm{~g}), \mathrm{Ca}(2.96 \mathrm{~g}), \mathrm{Mg}(0.83 \mathrm{~g})$ and $\mathrm{P}(0.41 \mathrm{~g})$ contents than when they were incorporated $(3.40,2.11,0.63$ and $0.35 \mathrm{~g}$, respectively) ( $p<0.05, p<0.01, p<0.01$ and $p<0.05$, respectively; Tab. V). Differences in Ca biomass content between surface and incorporation placement were greater for forest floor litter than for forest floor litter plus harvest residues (interaction residue $\times$ placement, $p<0.05$, Tab. V). Legume cover cropping positively affected $\mathrm{N}$ contents $(p<0.05)$ in biomass (Tabs. V and VII), but reduced biomass Ca content when only the forest floor litter layer was applied (interaction residue $\times$ legume, $p<0.01$ ).

\subsection{Leachate volume and nutrient leaching}

Rainfall and irrigation water amounted to $1611 \mathrm{~mm}$ during the experiment. The NR treatment had the largest leachate volume (430 mm, Fig. 1). Legume cover cropping reduced the accumulated volume leached by $15 \%(p=0.018)$ when compared with its absence. The greatest volume of leachate was measured during the early experimental period, that is, from January to June of 1998.

Mineral $\mathrm{N}$ was mostly leached during the first six months, with $47-93 \%$ of the $\mathrm{NO}_{3}^{-}-\mathrm{N}$ and $84-91 \%$ of the $\mathrm{NH}_{4}^{+}-\mathrm{N}$ being leached during the experimental period (Fig. 1). Nitrate was the dominant form of the mineral $\mathrm{N}$ (about 85\%). The largest mineral $\mathrm{N}_{-} \mathrm{NO}_{3}, \mathrm{Ca}$ and $\mathrm{Mg}$ losses (Fig. 1) were observed in the absence of organic residues (treatment NR), although significant differences were only detected relatively to $\mathrm{N}-\mathrm{NO}_{3}$ in treatments with legume (LL and LHL) and with harvest residues incorporated (LHI).

Residue type and placement and legume cover did not significantly affect leaching of $\mathrm{NO}_{3}, \mathrm{NH}_{4}, \mathrm{Ca}$ or $\mathrm{Mg}$. Accumulated loss of $\mathrm{K}$ was significantly affected by residue type $(p=0.0006)$, the values being greater in lysimeters with forest floor litter plus harvest residues $(547.4 \mathrm{mg} / \mathrm{lysimeter})$ than in those with forest floor litter only $(369.0 \mathrm{mg} / \mathrm{lysimeter})$. Over the first year of study, legume cover cropping reduced accumulated losses of $\mathrm{N}, \mathrm{Ca}, \mathrm{Mg}$ and $\mathrm{K}(40,25,28$ and 50\%, respectively) in relation to its absence.

\subsection{Soil chemical properties}

At the end of the experiment, values of $\mathrm{pH}-\mathrm{H}_{2} \mathrm{O}$ (Tab. VIII) in the $10 \mathrm{~cm}$ topsoil layer were significantly greater in the NR (5.67) than in the other treatments $(4.45-5.18)$. In the $0-30 \mathrm{~cm}$ soil layer, values in lysimeters with forest floor litter plus harvest residues were significantly reduced in relation to those with forest floor litter only $(p<0.001)$. A significant reduction was also observed for soil surface placement $(p<0.05)$.

Down to $30 \mathrm{~cm}$ topsoil depth, the presence of organic residues increased organic $\mathrm{C}$ and nutrient contents (total N, extractable $\mathrm{Ca}, \mathrm{Mg}, \mathrm{K}$ and $\mathrm{P}$ ) when compared with their absence (NR treatment), but significant differences were only observed for some treatments. Organic C contents in the LS (in the 0 $10 \mathrm{~cm}$ topsoil layer) and in the LHI treatments (at $20-30 \mathrm{~cm}$ ) were significantly greater than those observed in the NR. Total $\mathrm{N}$ contents in the NR were significantly lower than in the other treatments, except in the treatment LHS, at least in one layer down to $30 \mathrm{~cm}$ depth. Nevertheless, it is noted that $\mathrm{C}$ and $\mathrm{N}$ amounts corresponding to organic residues on the soil surface (LHS treatment) were not taken into account and, therefore, differences observed could be more pronounced in the long term.

In the 10-30 cm soil layer, contents of extractable $\mathrm{Ca}$ in treatments LL and LHI (and at least in one layer in treatments LS, LI and LHL) were significantly greater than in the NR. Extractable $\mathrm{Mg}$ contents were significantly greater than in the NR treatment (except LHS) at least in one layer down to $30 \mathrm{~cm}$ depth. Contents of extractable K in the NR were significantly lower than those observed in several layers of the LHI and LHL treatments. The LHI treatment showed mostly significant greater extractable $\mathrm{K}$ contents than in the treatments with forest floor litter only (LS, LI and LL). Extractable P contents in the control (10-30 cm soil layer) were significantly smaller than in the treatments LHI and LHL.

The effect of residue type on extractable $\mathrm{K}$ contents was observed in the $0-30 \mathrm{~cm}$ soil layer, being 38, 64 and $33 \%$ $(p=0.0009, p=0.0004$ and $p<0.05$ in $0-10,10-20$ and 20-30 cm, respectively) greater in lysimeters with forest floor litter plus harvest residues. Forest floor litter placed on the soil surface increased contents of $\mathrm{Ca}, \mathrm{Mg}, \mathrm{K}$ and $\mathrm{P}$ in the $0-10 \mathrm{~cm}$ topsoil layer as compared with their incorporation (interaction residue $\times$ placement, $p<0.05$ ). Incorporation of residues increased $\mathrm{Ca}, \mathrm{Mg}$ and $\mathrm{K}$ contents in the $10-20$ and $20-30 \mathrm{~cm}$ soil layers (about 22, 26 and 40\%, respectively). Legume cover did not significantly affect any of the elements for the analyzed depths. Legume cropping increased $\mathrm{N}$ content in the topsoil surface layer when combined with forest floor litter plus harvest residues (interaction residue $\times$ legume, $p<0.05$ ).

\section{DISCUSSION}

The methodology used in this study presents some limitations, as the soil structure and water transfers are disturbed in the lysimeter installation and the amounts of residues used are about two times greater than at the harvest of the first rotation of Pinus pinaster plantations (PROBRAVO, 2007). Although experimental conditions have a limited value in assessing the complexity of field situations, they give insight into the effect of harvest residues regarding growth and nutrition of $P$. pinaster, nutrient leaching and soil chemical properties. 


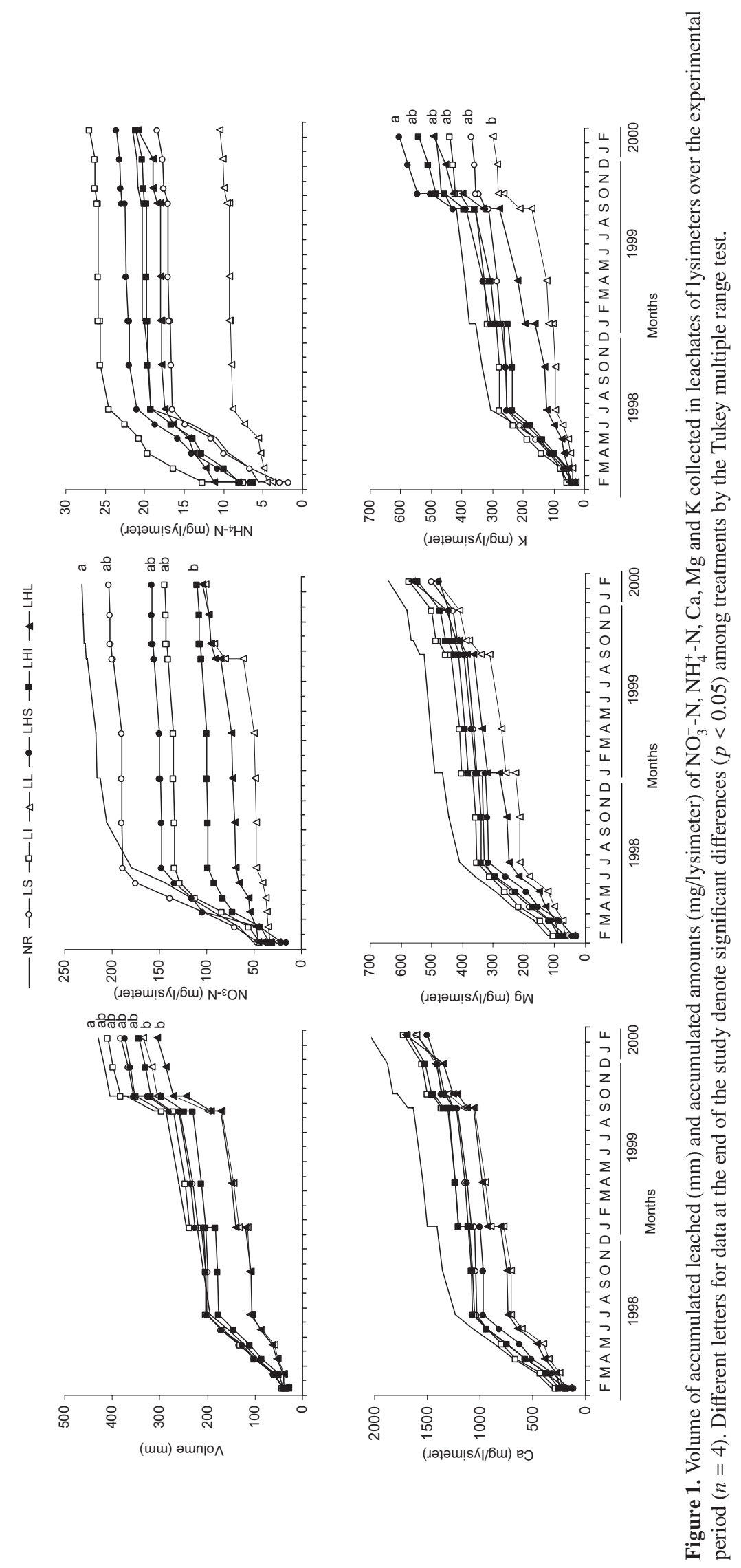


Table VIII. Values of $\mathrm{pH}$ and contents of organic $\mathrm{C}$ and total $\mathrm{N}\left(\mathrm{g} \mathrm{kg}^{-1}\right)$, extractable $\mathrm{Ca}, \mathrm{Mg}, \mathrm{K}\left(\mathrm{cmol}_{c} \mathrm{~kg}^{-1}\right)$ and $\mathrm{P}\left(\mathrm{mg} \mathrm{kg}^{-1}\right)$ according to soil depth.

\begin{tabular}{|c|c|c|c|c|c|c|c|}
\hline \multirow{2}{*}{$\begin{array}{l}\text { Prof. } \\
\mathrm{cm}\end{array}$} & \multicolumn{7}{|c|}{ Treatments } \\
\hline & NR & LS & LI & $\mathrm{LL}$ & LHS & LHI & LHL \\
\hline \multicolumn{8}{|c|}{$\mathrm{pH} \mathrm{H} \mathrm{H}_{2} \mathrm{O}$} \\
\hline $0-10$ & $5.67 \pm 0.16 \mathrm{a}$ & $5.02 \pm 0.13 b$ & $5.16 \pm 0.10 \mathrm{be}$ & $5.18 \pm 0.11 b$ & $4.45 \pm 0.12 \mathrm{c}$ & $4.87 \pm 0.11$ ef & $4.79 \pm 0.13 \mathrm{df}$ \\
\hline $10-20$ & $4.77 \pm 0.11 \mathrm{a}$ & $4.59 \pm 0.03 \mathrm{ac}$ & $4.63 \pm 0.05 \mathrm{ac}$ & $4.68 \pm 0.02 \mathrm{ac}$ & $4.23 \pm 0.13 b$ & $4.40 \pm 0.09 \mathrm{bd}$ & $4.54 \pm 0.05 \mathrm{~cd}$ \\
\hline $20-30$ & $5.13 \pm 1.02 \mathrm{a}$ & $4.48 \pm 0.14 \mathrm{ab}$ & $4.64 \pm 0.12 \mathrm{ab}$ & $4.71 \pm 0.11 \mathrm{ab}$ & $4.09 \pm 0.07 \mathrm{~b}$ & $4.41 \pm 0.07 \mathrm{ab}$ & $4.40 \pm 0.17 \mathrm{ab}$ \\
\hline \multicolumn{8}{|c|}{ Organic C } \\
\hline $0-10$ & $19.1 \pm 2.6 \mathrm{a}$ & $30.1 \pm 4.7 b$ & $27.7 \pm 2.7 \mathrm{ab}$ & $29.3 \pm 2.4 \mathrm{ab}$ & $28.7 \pm 7.8 \mathrm{ab}$ & $32.3 \pm 8.8 \mathrm{ab}$ & $32.9 \pm 3.4 \mathrm{ab}$ \\
\hline $10-20$ & $23.4 \pm 5.8$ & $33.3 \pm 11.3$ & $31.0 \pm 4.3 \mathrm{a}$ & $30.5 \pm 2.7$ & $26.0 \pm 1.8$ & $30.5 \pm 3.3$ & $30.1 \pm 12.8$ \\
\hline $20-30$ & $22.6 \pm 1.3 \mathrm{a}$ & $24.4 \pm 4.64 \mathrm{ab}$ & $28.5 \pm 2.5 \mathrm{ab}$ & $26.4 \pm 4.3 \mathrm{ab}$ & $30.2 \pm 4.6 \mathrm{ab}$ & $32.0 \pm 4.4 b$ & $30.3 \pm 2.5 \mathrm{ab}$ \\
\hline \multicolumn{8}{|c|}{ Total N } \\
\hline $0-10$ & $0.49 \pm 0.07 \mathrm{a}$ & $0.77 \pm 0.08 b$ & $0.76 \pm 0.16 b$ & $0.70 \pm 0.07 \mathrm{ab}$ & $0.59 \pm 0.05 a b$ & $0.68 \pm 0.17 \mathrm{ab}$ & $0.77 \pm 0.10 \mathrm{~b}$ \\
\hline $10-20$ & $0.43 \pm 0.03 \mathrm{a}$ & $0.63 \pm 0.05 b c$ & $0.71 \pm 0.08 \mathrm{bc}$ & $0.77 \pm 0.12 b$ & $0.54 \pm 0.10 \mathrm{ac}$ & $0.63 \pm 0.06 \mathrm{bc}$ & $0.74 \pm 0.12 b$ \\
\hline $20-30$ & $0.49 \pm 0.04 \mathrm{a}$ & $0.61 \pm 0.12 \mathrm{ab}$ & $0.67 \pm 0.07 \mathrm{ab}$ & $0.68 \pm 0.03 a b$ & $0.62 \pm 0.11 \mathrm{ab}$ & $0.71 \pm 0.13 a b$ & $0.73 \pm 0.15 b$ \\
\hline \multicolumn{8}{|c|}{ Extractable $\mathrm{Ca}$} \\
\hline $0-10$ & $2.94 \pm 0.37 \mathrm{ab}$ & $4.11 \pm 1.71 \mathrm{a}$ & $3.48 \pm 0.05 \mathrm{ab}$ & $3.12 \pm 0.69 \mathrm{ab}$ & $3.24 \pm 0.28 b$ & $3.46 \pm 0.35 \mathrm{ab}$ & $3.22 \pm 0.21 \mathrm{ab}$ \\
\hline $10-20$ & $1.68 \pm 0.16 \mathrm{a}$ & $2.28 \pm 0.21 b c$ & $2.47 \pm 0.06 b$ & $2.40 \pm 0.25 b c$ & $1.87 \pm 0.17 \mathrm{ac}$ & $2.66 \pm 0.45 b$ & $2.40 \pm 0.27 b c$ \\
\hline $20-30$ & $1.82 \pm 0.27 \mathrm{a}$ & $1.97 \pm 0.19 \mathrm{ac}$ & $2.33 \pm 0.10 a b$ & $2.53 \pm 0.37 b c$ & $2.04 \pm 0.20 \mathrm{ac}$ & $2.80 \pm 0.30 \mathrm{~b}$ & $2.30 \pm 0.32 \mathrm{ab}$ \\
\hline \multicolumn{8}{|c|}{ Extractable $\mathrm{Mg}$} \\
\hline $0-10$ & $0.32 \pm 0.02 \mathrm{a}$ & $0.69 \pm 0.21 b$ & $0.53 \pm 0.04 \mathrm{ab}$ & $0.54 \pm 0.12 a b$ & $0.50 \pm 0.08 \mathrm{ab}$ & $0.64 \pm 0.24 \mathrm{~b}$ & $0.63 \pm 0.08 \mathrm{ab}$ \\
\hline $10-20$ & $0.27 \pm 0.05 \mathrm{a}$ & $0.43 \pm 0.07 a b$ & $0.50 \pm 0.02 b$ & $0.49 \pm 0.04 \mathrm{ab}$ & $0.40 \pm 0.05 \mathrm{ab}$ & $0.63 \pm 0.16 b$ & $0.62 \pm 0.18 b$ \\
\hline $20-30$ & $0.33 \pm 0.06 \mathrm{a}$ & $0.43 \pm 0.04 \mathrm{ab}$ & $0.52 \pm 0.01 \mathrm{bc}$ & $0.53 \pm 0.06 b c$ & $0.48 \pm 0.06 \mathrm{ab}$ & $0.66 \pm 0.15 \mathrm{c}$ & $0.49 \pm 0.06 \mathrm{ab}$ \\
\hline \multicolumn{8}{|c|}{ Extractable $\mathrm{K}$} \\
\hline $0-10$ & $0.06 \pm 0.01 \mathrm{a}$ & $0.12 \pm 0.03 a b$ & $0.09 \pm 0.01 \mathrm{ac}$ & $0.06 \pm 0.02 \mathrm{a}$ & $0.13 \pm 0.02 b c$ & $0.14 \pm 0.04 \mathrm{~b}$ & $0.13 \pm 0.03 b c$ \\
\hline $10-20$ & $0.03 \pm 0.00 \mathrm{a}$ & $0.06 \pm 0.01 \mathrm{a}$ & $0.06 \pm 0.01 \mathrm{ac}$ & $0.06 \pm 0.01 \mathrm{a}$ & $0.08 \pm 0.00 \mathrm{ac}$ & $0.15 \pm 0.08 \mathrm{~b}$ & $0.13 \pm 0.03 b c$ \\
\hline $20-30$ & $0.05 \pm 0.01 \mathrm{a}$ & $0.06 \pm 0.01 \mathrm{a}$ & $0.10 \pm 0.07 \mathrm{ab}$ & $0.07 \pm 0.01 \mathrm{ab}$ & $0.09 \pm 0.01 \mathrm{ab}$ & $0.13 \pm 0.02 b$ & $0.09 \pm 0.01 \mathrm{ab}$ \\
\hline \multicolumn{8}{|c|}{ Extractable P } \\
\hline $0-10$ & $5.5 \pm 1.7$ & $8.2 \pm 2.3$ & $5.0 \pm 0.8$ & $6.6 \pm 1.8$ & $6.6 \pm 2.9$ & $9.9 \pm 3.3$ & $9.7 \pm 1.3$ \\
\hline $10-20$ & $3.7 \pm 1.1 \mathrm{a}$ & $4.9 \pm 0.9 \mathrm{ac}$ & $5.1 \pm 0.8 \mathrm{ac}$ & $5.6 \pm 1.1 \mathrm{ac}$ & $3.4 \pm 1.2 \mathrm{a}$ & $8.8 \pm 2.5 \mathrm{~b}$ & $7.4 \pm 0.9 \mathrm{bc}$ \\
\hline $20-30$ & $1.5 \pm 1.1 \mathrm{a}$ & $3.4 \pm 0.7 \mathrm{ac}$ & $2.6 \pm 1.4 \mathrm{a}$ & $2.8 \pm 1.3 \mathrm{ac}$ & $4.8 \pm 0.6 \mathrm{ab}$ & $8.7 \pm 3.1 \mathrm{~b}$ & $6.9 \pm 2.8 \mathrm{bc}$ \\
\hline
\end{tabular}

Different letters in the same row denote significant differences $(p<0.05)$ among treatments by the Tukey multiple range test. Values are means $(n=4)$ \pm S.D.

In the present study, organic residues on the soil surface improved seedling growth in comparison with their incorporation. Other authors have also reported enhanced growth of pine (Egnell and Valinger, 2003) and eucalypt (Mendham et al., 2003; Nzila et al., 2001) in low fertility soils with harvest residues maintained on the soil surface. However, limited effect has also been reported in Douglas-fir (Roberts et al., 2005) and eucalypt plantations (Mendham et al., 2001) with relatively high fertility, suggesting that the effect of residue management on tree growth may vary with site quality. Our results are in line with those observed in a similar experiment with Eucalyptus globulus by Soares et al. (2002), who suggest that improvement of seedling growth through harvest residue placement on the soil surface could be related to greater root development. However, other factors might be involved, such as the lower $\mathrm{N}$ and $\mathrm{P}$ immobilization reported by Carlyle et al. (1998) for this placement in relation to their incorporation, which is also in agreement with the lower $\mathrm{N}$ and $\mathrm{P}$ influxes to roots as reported by Soares et al. (2002). Residues placed on the soil surface may also reduce soil water evaporation, as observed in a lysimetric (Gómez-Rey et al., 2007) and a field (Pérez-Batallón et al., 2001) experiment. Therefore, as already suggested for pine seedlings planted under Mediterranean conditions (Valdecantos et al., 2006), water availability may have positively influenced seedling growth.

Amounts of $\mathrm{N}, \mathrm{Ca}$ and $\mathrm{Mg}$ leached from the soil were low when compared with the amount supplied. For example, the amount of $\mathrm{N}$ leached $(254 \mathrm{mg})$ in the absence of organic residues over the study period was of the same magnitude as the mean annual input through rainfall (194 mg), and it was only $14 \%$ of $\mathrm{N}$ applied as fertilizers. This low leaching may be explained by the high soil $\mathrm{C} / \mathrm{N}$ ratio (35.8) which is above the critical condition for $\mathrm{N}$ release. In addition, the low $\mathrm{N}$ leaching observed in treatments with residues may be related to the high $\mathrm{C} / \mathrm{N}$ ratio of forest floor litter (72) and harvest residues (67 and 185 for needles and branches, respectively), which may act as 
a sink for $\mathrm{N}$ during their decomposition (Ganjegunte et al., 2004; Hyvönen et al., 2000) and contribute to maintaining N in the system. This is also in agreement with the fact that $\mathrm{N}$ assimilated by tree seedlings was of the same magnitude as that observed in the absence of residues. Therefore, the maintenance of residues in the site may contribute to enhancing soil $\mathrm{N}$ fertility in the long term, as losses through leaching were negligible. However, it has been reported that the maintenance of organic residues may induce $\mathrm{N}$ deficiency during the early stages of tree growth in $\mathrm{N}$-poor sites (Mendham et al., 2003). In fact, during the first year of the experiment, contents of $\mathrm{N}$ in seedling needles of treatments with organic residues were lower than in their absence, but this difference was not associated with reduced tree growth. In addition, the similarity in needle $\mathrm{N}$ contents, $\mathrm{N}$ amounts accumulated by seedlings and $\mathrm{N}$ losses through leaching, at the end of the study, suggest that maintenance of residues did not enhance $\mathrm{N}$ availability during the study period. Nitrogen contents observed in needles are of the same magnitude as those measured in similar treatments applied over two years in the field (PROBRAVO, 2007), that is, in the site from which the present experimental soil and residues were collected.

Harvest residues have a positive influence on $\mathrm{K}$ nutrition, as two years after planting a significant increase in green needle $\mathrm{K}$ contents and pine seedlings was observed in the treatments where they were applied. Also, greater K losses by leaching and extractable $\mathrm{K}$ accumulation in the soil were observed. This may be explained by the high mobility of $\mathrm{K}$, which is readily leached from decomposing pine residues (Ganjegunte et al., 2004; Xu, 2006). In addition, this trend might also be increased by the double amount of residues applied in treatments with harvest residues. In fact, contents of $\mathrm{K}$ in needle seedlings were slightly greater than those reported for similar seedlings under field conditions, where the amount of experimental residues was not doubled (PROBRAVO, 2007).

An enhancement of organic $\mathrm{C}$ and $\mathrm{N}$ contents was observed at the end of the study in the mineral substrate, due to the presence of organic residues. This was noticeable along soil depth in treatments with both forest floor and harvest residues, and it was independent of their placement. In the top 0-30 cm soil layer, an increase in organic C (33-51\%) and total $\mathrm{N}(24-60 \%)$ contents was observed in the presence of organic residues relatively to their absence. These results are in agreement with those reported by Chen and Xu (2005), who observed a favorable effect of residue maintenance on soil $\mathrm{C}$ and $\mathrm{N}$ status in a pine plantation grown in sandy soils, and also by Madeira and Ribeiro (1995) in a lysimeter experiment with needle litter applied on a sandstone substrate. However, our results did not agree with those by Olsson et al. (1996a) and Mendham et al. (2003), for sandy soils, as soil C and N status were not affected by harvest residue management. Such a difference may be related to the low amounts of $\mathrm{C}$ in the soils of the present study.

The small response to residue management practices observed for nutrient losses, through leaching, suggests that nutrients released from residues should have been accumulated in the soil. As organic residues contained substantial amounts of nutrients, their presence also improved the pool of ex- tractable base cations in the topsoil layer $(0-10 \mathrm{~cm})$, following the trend observed by Olsson et al. (1996b) in podsolized soils of pine stands, and by Johnson and Todd (1998) in a temperate mixed oak forest. However, $\mathrm{Ca}$ and $\mathrm{Mg}$ contents decreased in the $10-30 \mathrm{~cm}$ soil layer in all treatments (especially in the absence of organic residues), which may be explained through transfer to deeper soil layers; this transfer was more pronounced by residue incorporation into the soil. Although a net $\mathrm{Ca}$ and $\mathrm{Mg}$ loss from the system was not observed, their allocation in soil deeper layers could negatively affect the availability for young trees' roots. Moreover, the incorporation of forest floor plus harvest residues also favored the transference of $\mathrm{K}$ and $\mathrm{P}$ to a soil depth beyond $30 \mathrm{~cm}$.

During the first year of study, legume cover reduced N, Ca, $\mathrm{Mg}$ and $\mathrm{K}$ losses, which may be related to nutrient uptake by legumes, and to the decrease in water drainage, which was the lowest in the respective treatments. As these differences were not observed at the end of the study period, the results suggest that legume cover does not significantly affect nutrient losses in the long term. Treatment with legumes led to an improvement in $\mathrm{N}$ status in seedlings and needles, as reported by Nambiar and Nethercott (1987) in radiate pine plantations on sandy soils with low fertility. However, soil $\mathrm{N}$ fertility was not affected by legume cover, as $\mathrm{N}$ content in the topsoil layer was only enhanced when it was combined with harvest residues. This may be ascribed to the low $\mathrm{N}$ content in the legume plants used, which was not sufficient to counteract the effect of organic residues on $\mathrm{N}$ immobilization.

Despite the potential for legumes to compete with seedlings for site resources, seedling growth was not affected by their use, which supports data reported on the effect of legume cover cropping during the early growth of pine (Simpson et al., 2004) and eucalyptus plantations (Mendham et al., 2004). Although, in the short term, the growth of pine seedlings and soil $\mathrm{N}$ fertility were not influenced by this practice, the benefits observed on $\mathrm{N}$ loss reduction trough leaching during early stages of plantation development and on $\mathrm{N}$ availability improvement may contribute to enhancing forest plantation productivity in the next rotations.

\section{CONCLUSIONS}

The maintenance of forest floor litter and harvest residues during the inter-rotation period may contribute, in the short term, to reducing nutrient losses from leaching and to improving soil nutrient status in the first years of pine plantations. In addition, seedling growth was dependent on the placement method, as it was improved by the maintenance of residues on the soil surface, but not by their incorporation into the soil, with or without legumes. Although seedling growth improvement was not associated with its nutrient status, positive effects observed on soil fertility through residue maintenance and legumes may contribute to long-term nutrient supply to pine plantations and, thus, to ensuring sustained productivity. However, appropriate field studies are needed to evaluate these effects over a longer period. 
Acknowledgements: The study was developed within the activities of the project Praxis 3/3.2/Flor/2123/95. The laboratory staff of the Departamento de Ciências do Ambiente (Instituto Superior de Agronomia) are acknowledged for their technical assistance with analytical work. Paulo Marques and Luis Hilário are also acknowledged for their assistance with measurements and samplings. The authors thank Prof. Ana Carla Madeira for her comments, which helped to improve the English.

\section{REFERENCES}

Aggangan R.T., O’Connell A.M., McGrath J.F., and Dell B., 1999. The effects of Eucalyptus globulus Labill. leaf litter on C and N mineralization in soils from pasture and native soils. Soil Biol. Biochem. 31: $1481-1487$.

Alley J.L., Garrett H.E., McGraw R.L., Dwyer J.P., and Blanche C.A., 1999. Forage legumes as living mulches for trees in agroforestry practices - preliminary results. Agrofor. Syst. 44: 281-291.

Carlyle J.C., Bligh M.W., and Nambiar E.K.S., 1998. Woody residue management to reduce nitrogen and phosphorus leaching from sandy soil after clear-felling Pinus radiata plantations. Can. J. For. Res. 28: $1222-1232$.

Chen C.R. and Xu Z.H., 2005. Soil carbon and nitrogen pools and microbial properties in a 6-year-old slash pine plantation of subtropical Australia: impacts of harvest residue management. For. Ecol. Manage. 206: 237-247.

Corbeels M., O'Connell A.M., Grove T.S., Mendham D.S., and Rance S.J., 2003. Nitrogen release from eucalypt leaves and legume residues as influenced by their biochemical quality and degree of contact with soil. Plant Soil 250: 15-28.

Dambrine E., Vega A., Taboada T., Rodríguez L., Fernández C., Macias F., and Gras J.M., 2000. Bilans d'éléments minéraux dans des petits bassins versants forestiers de Galice. Ann. For. Sci. 57: 23-38.

De Leenheer L. and Van Hove J., 1958.Determination de la teneur en carbone organique des sols. Étude critique des méthodes titrimétriques. Pédologie 8: 39-77.

DGRF, 2006. Estratégia Nacional para as Florestas. Versão intermédia, Direcção Geral dos Recursos Florestais, Lisboa.

Egnell G. and Valinger E., 2003. Survival, growth, and growth allocation of planted Scots pine trees after different levels of biomass removal in clear-felling. For. Ecol. Manage. 177: 65-74.

Egnér H., Riehm H., and Domingo WR., 1960. Untersuchungen über die chemische Bodenanalyse als Grundlage für die Beurteilung des Nährstoff-zustandes der Böden. II. Chemische Extraktionmethod zur Phosphor-und Kaliumbestimmung, Kungl. Lantbr. Högsk. Ann. 26: 199.

Ganjegunte G.K., Condron L.M., Clinton P.W., Davis M.R., and Mahieu N., 2004. Decomposition and nutrient release from radiata pine (Pinus radiata) coarse woody debris. For. Ecol. Manage. 187: 197211.

Gakis S., Mantzanas K., Alifragis D., Papanastasis V.P., Papaioannou A., Seilopoulos D., and Platis P., 2004. Effects on understorey vegetation on tree establishment and growth in a silvopastoral system in northern Greece. Agroforest. Syst. 60: 149-157.

Gómez-Rey M.X., Vasconcelos E., and Madeira M., 2007. Lysimetric study of eucalypt residue management effects on $\mathrm{N}$ leaching and mineralization. Ann. For. Sci. 64: 699-706.
Houba V.J.G., Novozamsky I., and Tenminghoff E., 1994. Soil analysis Procedures, Department of Soil Science and Plant Nutrition. Wageningen Agricultural University, The Netherlands.

Hyvönen R., Olsson B.A., Lundkvist H., and Staaf H., 2000. Decomposition and nutrient release from Picea abies (L.) Karst. and Pinus sylvestris L. logging residues. For. Ecol. Manage. 126: 97-112.

INMG, 2007. Normais climáticas da Tapada da Ajuda, 1971/2000. http://www.isa.utl.pt/dca/Clim_Rec_Hidr/index.html. Accessed 25 November 2007.

IFN, Inventário Florestal Nacional (2005-2006). 2006. Divisão de Inventário e Estatísticas Florestais, Direcção Geral das Florestas, Lisboa.

Johnson D.W., 1995. Role of carbon in the cycling of other nutrients in forested ecosystems. In: McFee W.W., Kelly J.M. (Eds.), Carbon forms and functions in forest soils, Soil Sci. Soc. America Inc., Reno, USA, pp. 299-328.

Johnson D.W. and Todd D.E., 1998. Harvesting effects on long-term changes in nutrient pools of mixed oak forest, Soil Sci. Soc. Am. J. 62 : $1725-1735$.

Madeira M. and Ribeiro C., 1995. Influence of leaf litter type on the chemical evolution of a soil parent material (sandstone). Biogeochemistry 29: 43-58.

Mendham D.S., O'Connell A.M., Grove T.S. and Rance S.J., 2003. Residue management effects on soil carbon and nutrient contents and growth of second rotation eucalypts. For. Ecol. Manage. 181: 357372.

Mendham D.S., Kumaraswamy S., Balasundaran M., Sankaran K.V., Corbeels M., Grove T.S., O'Connell A.M. and Rance S.J., 2004. Legume cover cropping effects on early growth and soil nitrogen supply in eucalypt plantations in south-western India. Biol. Fertil. Soils 39: $375-382$.

Merino A., Edeso J.M., González M.J., and Marauri P., 1998. Soil properties in a hilly area following harvesting management practices. For. Ecol. Manage. 103: 235-246.

Nambiar E.K.S. and Nethercott K.H., 1987. Nutrient and water availability to and growth of young radiate pine plantations intercropped with lupins. New Forest, 1: 117-134.

Nzila J.D., Bouillet J.P., Laclau J.P., and Ranger J., 2002. The effects of slash management on nutrient cycling and tree growth in Eucalyptus plantations in the Congo. For. Ecol. Manage. 171: 209-221.

Olsson B.A., Staaf H., Lundkvist H., Bengtsson J., and Rosén K., 1996. Carbon and nitrogen in coniferous forest soils after clear-felling and harvest of different intensity. For. Ecol. Manage. 82:19-32.

Olsson B.A., Bengtsson J., and Lundkvist H., 1996. Effects of different forest harvest intensities on the pools of exchangeable cations in coniferous forest soils. For. Ecol. Manage. 84: 135-147.

Pérez-Batallón P., Ouro G., Macías F., and Merino A., 2001. Initial mineralization of organic matter in a forest plantation soil following different logging residue management techniques. Ann. For. Sci. 58: 807-818.

Póvoas I. and Barral M.F., 1992. Métodos de Análises de Solos, Comunicações do IICT, Instituto de Investigação Científica Tropical, Série de Ciências Agrárias, 10, Lisboa.

PRAXIS, 2001. Preparação do solo e gestão da matéria orgânica para a productividade, sustentabilidade e biodiversidade dos sistemas florestais, Final Report, Instituto Superior de Agronomia, Lisboa. 
PROBRAVO, 2007. Sustainable management and enhancement of productivity, economic value and environmental performance of maritime pine systems, Final Report, Instituto Superior de Agronomia, Lisboa.

Roberts S.D., Harrington C.A. and Terry T.A., 2005. Harvest residues and competing vegetation affect soil moisture, soil temperature, $\mathrm{N}$ availability, and Douglas-fir seedling growth. For. Ecol. Manage. 205: 333-350.

Simpson J.A., Smith T.E., Keay P.T., Osborne D.O., Xu Z.H. and Podberscek M.I., 2004. Impacts of inter-rotation site management on tree growth and soil properties in the first 6.4 years of a hybrid pine plantation in subtropical Australia. In: Nambiar E.K.S., Ranger J., Tiarks A., Toma T. (Eds.), Site Management and Productivity in tropical plantation forests, Proceedings of workshops in Congo July 2001 and China February 2003, Center for International Forestry Research, Bogor, Indonesia, pp. 139-149.

Smethurst P.J. and Nambiar E.K.S., 1990. Effects of slash and litter management on fluxes of nitrogen and tree growth in a young Pinus radiata platation. Can. J. For. Res., 20: 1498-1507.
Smethurst P.J. and Nambiar E.K.S., 1995. Changes in soil carbon and nitrogen during the establishment of a second crop of Pinus radiate. For. Ecol. Manage. 73: 145-155.

Soares H., Madeira M., Fabião A., Azevedo A., Kätterer T., Abreu F. and Cortez N, 2002. Efeitos da gestão de resíduos de abate no crescimento inicial de Eucalyptus globulus Labill.: resultados de um estudo lisimétrico. Rev. Ciências Agr. 25: 394-412.

Valdecantos A., Cortina J., and Vallejo, V.R., 2006. Nutrient status and field performance of tree seedlings planted in Mediterranean degraded areas. Ann. For. Sci. 63: 249-256.

WRB, 2006. World reference base for soil resources 2006, 2nd ed. World Soil Resources Reports No. 103, FAO, Rome.

Xu X., 2006. Nutrient dynamics in decomposing needles of Pinus luchuensis after typhoon disturbance in a subtropical environment. Ann. For. Sci. 63: 707-713. 